\title{
Detectable HIV-1 in semen in individuals with very low blood viral loads
}

\author{
Samuel Mundia Kariuki ${ }^{1,2,3}$, Philippe Selhorst ${ }^{4,5}$, Jennifer Norman ${ }^{6}$, Karen Cohen ${ }^{6}$, Kevin Rebe ${ }^{7,8}$, \\ Carolyn Williamson ${ }^{4,9,10}$ and Jeffrey R. Dorfman ${ }^{1,11^{*}}$ (D)
}

\begin{abstract}
Background: Several reports indicate that a portion (5-10\%) of men living with HIV-1 intermittently shed HIV-1 RNA into seminal plasma while on long term effective antiretroviral therapy (ART). This is highly suggestive of an HIV-1 reservoir in the male genital tract. However, the status of this reservoir in men living with HIV-1 who are not under treatment is underexplored and has implications for understanding the origins and evolution of the reservoir.

Finding: Forty-three HIV-1 positive, antiretroviral therapy naive study participants attending a men's health clinic were studied. Semen viral loads and blood viral loads were generally correlated, with semen viral loads generally detected in individuals with blood viral loads $>10,000 \mathrm{cp} / \mathrm{ml}$. However, we found 1 individual with undetectable viral loads $(<20 \mathrm{cp} / \mathrm{ml})$ and 2 individuals with very low blood viral load (97 and 333cp/ml), but with detectable HIV-1 in semen (485-1157 copies/ semen sample). Blood viral loads in the first individual were undetectable when tested three times over the prior 5 years.

Conclusions: Semen HIV-1 viral loads are usually related to blood viral loads, as we confirm. Nonetheless, this was not true in a substantial minority of individuals suggesting unexpectedly high levels of replication in the male genital tract in a few individuals, despite otherwise effective immune control. This may reflect establishment of a local reservoir of HIV-1 populations.
\end{abstract}

Keywords: HIV-1, Semen, Blood, Viral load

\section{Introduction}

Several reports in a range of settings globally indicate that a portion (5-10\%) of men living with HIV-1 intermittently shed HIV-1 RNA into seminal plasma while on long term effective antiretroviral therapy (ART) [1-5]. In a series of observational studies, viral suppression with antiretroviral therapy is associated with no detectable risk of transmission [6], even in populations of men having sex with men with high rates of sexually transmitted infections and evidence for high rates of high risk sex [7]. The reason that HIV-1 RNA shed into semen is not associated

\footnotetext{
* Correspondence: jeffrey.dorfman@uct.ac.za

'Division of Immunology, Department of Pathology, University of Cape Town, Anzio Rd, Observatory, Cape Town 7925, South Africa

${ }^{11}$ Division of Virology, Faculty of Medicine and Health Sciences, Stellenbosch University, Parow, South Africa

Full list of author information is available at the end of the article
}

with a detectable risk of transmission is unclear. Plausibly, the proportion of virions that are viable in this context is low [8] and thus an infectious dose of viable virions is not reached. Nonetheless, the presence of HIV-1 RNA in semen is highly suggestive of an HIV-1 reservoir in the male genital tract [9]. However, the status of this reservoir in men living with HIV-1 not under treatment is underexplored and has implications for understanding the origins and evolution of the reservoir.

The presence of HIV-1 RNA during effective ART is very likely indicative of persisting HIV-1 production in the male genital tract because the half-life of HIV-1 virions in serum is less than $8 \mathrm{~h}[10]$. The reason production of HIV-1 is able to persist in the male genital tract is not clear. In some cases, penetration of ART drugs into the male genital tract may be incomplete, but the picture is complex and a simple association is not obvious [11].

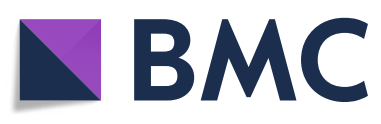

(C) The Author(s). 2020 Open Access This article is licensed under a Creative Commons Attribution 4.0 International License, which permits use, sharing, adaptation, distribution and reproduction in any medium or format, as long as you give appropriate credit to the original author(s) and the source, provide a link to the Creative Commons licence, and indicate if changes were made. The images or other third party material in this article are included in the article's Creative Commons licence, unless indicated otherwise in a credit line to the material. If material is not included in the article's Creative Commons licence and your intended use is not permitted by statutory regulation or exceeds the permitted use, you will need to obtain permission directly from the copyright holder. To view a copy of this licence, visit http://creativecommons.org/licenses/by/4.0/ The Creative Commons Public Domain Dedication waiver (http://creativecommons.org/publicdomain/zero/1.0/) applies to the data made available in this article, unless otherwise stated in a credit line to the data. 
In this report, we studied men living with HIV-1 at a Men's clinic in Cape Town, South Africa who were not yet on ART. We found individuals who were apparently capable of suppressing their viral loads in the blood circulation, but nonetheless did shed HIV-1 RNA into their semen.

\section{Materials and methods}

\section{Study participants}

Forty-three HIV-1 positive, ART-naive study participants were recruited between June 2015 and January 2017 from ANOVA Health's Ivan Toms Health4Men clinics in Woodstock, Green Point or Khayelitsha, all in Cape Town, South Africa. Study participants were scheduled for sample collection and interview when the clinic was otherwise closed and were asked to abstain from sexual activity for $72 \mathrm{~h}$ prior to sample collection. For each study participant, both blood and semen samples were collected during a single visit. Study participants were interviewed and clinical records were reviewed to identify current and recent sexually transmitted infections (STIs) and clinical history. Study participants all self-reported to be ART naive and none previously received ART from Ivan Toms Health4Men clinics.

\section{Sample handling and testing}

The entire specimen of semen was diluted 1:1 with phosphate buffered saline (PBS) and then underlaid with 19\% Nycodenz (Axis-Shield PoC AS, Oslo, Norway) in PBS with penicillin/streptomycin and centrifuged (1000 g, $20 \mathrm{~min})$ to separate seminal plasma from sperm and other cells. Seminal plasma was recovered, filtered $(0.8 \mu \mathrm{m})$ and HIV-1 was concentrated by centrifugation $\left(100,000 \mathrm{~g}, 1 \mathrm{~h} 4^{\circ} \mathrm{C}\right)$. The pellet was resuspended in $200 \mu \mathrm{l}$ of PBS, $40 \mu \mathrm{l}$ of which was diluted to $500 \mu \mathrm{l}$ and assayed for viral load. The limit of detection under these conditions was $100 \mathrm{cp}$ (copies)/ml, corresponding to $250 \mathrm{cp} / \mathrm{semen}$ sample. Viral loads were measured in a clinically accredited laboratory (National
Health Laboratory Service, Groote Schuur Hospital, Cape Town) by the Roche COBAS AmpliPrep/TaqMan methodology. Blood samples were scored as undetectable only if the viral load was undetectable at the time of collection and also in a confirmatory test performed later on frozen blood plasma.

\section{Results and discussion}

Median age was 29 years (IQR 25-36); median CD4 ${ }^{+} \mathrm{T}$ cell count was 519 cells/ $\mu$ l (IQR 370-631), and median blood viral load was $4.10 \log _{10} \mathrm{cps} / \mathrm{ml}$ (IQR 2.69-4.56). Generally, HIV-1 was detected in semen in samples with blood viral load $>10,000 \mathrm{cp} / \mathrm{ml}$ (Fig. 1) and for those samples, the $\log _{10}$ semen viral loads correlated moderately with the $\log _{10}$ blood viral loads $\left(R^{2}=0.1556, p=0.026\right)$. This is in line with previous studies showing a similar correlation, with thresholds ranging from 2000 to 10,000cp/ml [12-16] (reviewed in [17]). Some studies comparing blood to semen viral loads had very few individuals with blood viral loads below 10 , $000 \mathrm{cp} / \mathrm{ml}$ [18-20], possibly because they included many individual with low $\mathrm{CD}^{+} \mathrm{T}$ cell counts.

The rough correlation between the two measures and apparent threshold effect suggests that HIV-1 in the male genital tract is ultimately fed from the larger HIV-1 populations in blood/general circulation (Kariuki SM, P. S, Anthony A, Matten D, Abrahams MR, Martin DP, Ariën KA, Rebe K, Williamson C, Dorfman JR: Compartmentalization and clonal amplification of HIV-1 in the male genital tract characterized using next generation sequencing, submitted for publication). This is in contrast to what is found by Klein et al [21] in the genital tracts of women with early stage HIV-1 infections. There, the blood populations appeared to be derived from those found in the genital mucosa. It is possible that HIV-1 could reach the male genital tract from the blood circulation in cases in which external male sex

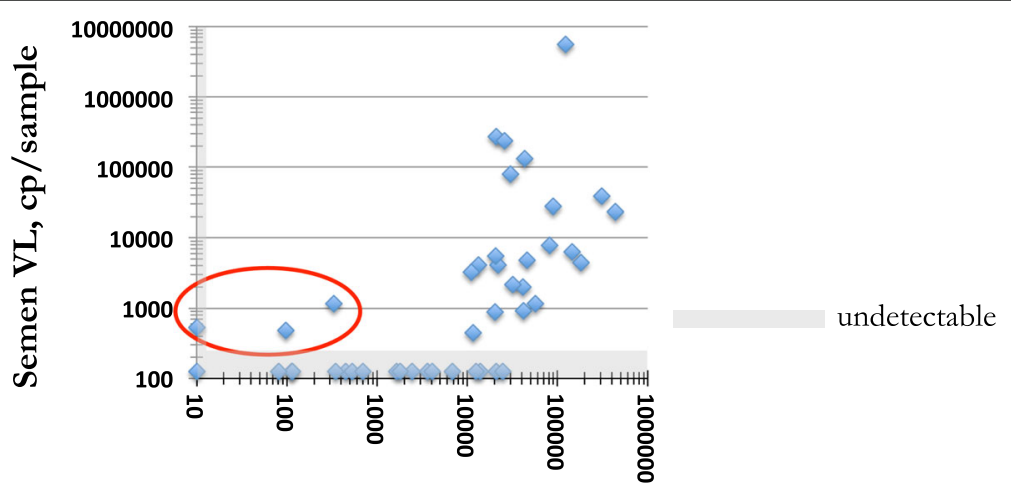

Blood VL, cp/ml

Fig. 1 Display of blood viral load (cp/ml) vs semen viral load (cp/sample) for the 43 individual men in this study. Values plotted as $10 \mathrm{cp} / \mathrm{ml}$ or $125 \mathrm{cp} / \mathrm{sample}$ reflect undetectable viral loads. The red circle encloses the 3 individuals with detectable viral loads in semen but low or undetectable viral loads in blood 
organs were the original site of inoculation. Additionally, there may be differences in the site of the original HIV-1 inoculation in the participants in the present study, perhaps due to high intravenous drug use in the population from which our study participants were drawn [22] and/ or inoculation via the rectum. In such cases, HIV-1 reaching the male genital tract presumably did so via the blood circulation.

More interestingly, we found 1 individual with undetectable viral loads $(<20 \mathrm{cp} / \mathrm{ml})$ and 2 individuals with very low blood viral load $(97$ and $333 \mathrm{cp} / \mathrm{ml})$, but with detectable HIV-1 in semen, ranging from 485 to 1157 copies/semen sample (Fig. 1). These did not fit the pattern of correlation between blood and semen viral loads. The individual that had undetectable blood viral load, had undetectable blood viral loads when tested previously, approximately 3 and 5 years prior. $\mathrm{CD}^{+} \mathrm{T}$ cell counts of these three individuals (range 403-1123 cells/ $\mu \mathrm{l}$ ) were not significantly different from the other study participants $(p=0.14)$, nor was age $(p=0.51)$. None of the three individuals reported sexually transmitted infections (STIs) and no STIs were detected upon clinical folder inspection or clinician interviews on the day of sample collection. The small sample size prevents meaningful statistical comparison.

The detection of HIV-1 viral loads in seminal plasma in these individuals suggests that even highly effective immune responses maintained for extended periods are not always sufficient to suppress shedding of HIV-1 RNA into seminal plasma. A review of prior data reveal that other studies may have observed one or two individuals each with such patterns [12-16] (Figure S1). None of these studies commented upon these individuals. A recent report [23] studied $10 \mathrm{HIV}-1$ controllers and measured secretion of HIV-1 RNA into seminal plasma. HIV-1 RNA over $40 \mathrm{cp} / \mathrm{ml}$ in semen of the HIV-1 controllers was detected, but only in individuals with relatively high contemporaneous or 30-day prior blood viral loads $(685-5750 \mathrm{cp} / \mathrm{ml})$. It thus seemed possible from that study that the HIV-1 found in semen could have been recently sourced from the systemic circulation. Here, we describe individuals with lower contemporaneous blood viral loads, including one with three blood viral loads below the detection limit over 5 years.

Individuals with an HIV-1 reservoir in the male genital tract may be more common than we observe because (i) they would be less obvious when reservoir-derived HIV1 RNA is intermingled with RNA from recent migrants from robust HIV-1 populations in the blood circulation, and because (ii) not all reservoirs necessarily give rise to HIV-1 RNA secreted into semen at all times. In support of the idea of the male genital tract as a potential reservoir, recent work has suggested that a substantial reservoir of HIV-1 persists during antiretroviral therapy in urethral macrophages in the male genital tract [24].
Most study participants in the current study, including the three individuals with this phenotype, received their primary care at the Ivan Toms clinic at which recruitment took place, and none had been offered ART before the samples were collected. All study participants were also asked to confirm that they were not on ART. Additionally, all three individuals with this phenotype were tested for antiretroviral drugs in two ways: (i) serum of each individual was tested for the ability to inhibit entry and subsequent gene expression of HIV-1 pseudotyped viruses expressing the envelope of murine leukaemia virus (MLV) [25]; (ii) blood plasma was tested for the presence of efavirenz and lopinavir by liquid chromatography tandem mass spectrometry (LC MS/MS, qualitative test with limit of detection $0.02 \mu \mathrm{g} / \mathrm{ml}$ for both drugs). Efavirenz and boosted lopinavir were the standard backbones for first and second line ART, respectively, for adult men receiving ART in the public sector in South Africa at the time of recruitment. The limit of detection of the antiretroviral assays is considerably lower than the minimum trough concentration recommended for efficacy $(1 \mu \mathrm{g} / \mathrm{ml}$ for both drugs [26]).

Antiretroviral drugs were not detected by either method. The inability to inhibit MLV pseudotyped HIV-1 suggests that no antiretroviral drug was present at functional concentrations. The LC MS/MS result indicates that it is highly unlikely that efavirenz in normally prescribed doses was taken in the 7 days prior to sample collection or lopinavir in the $24 \mathrm{~h}$ prior to sampling. The time window is wider for efavirenz because of its longer half-life [27].

The presence of HIV-1 RNA in seminal plasma of individuals whilst on ART has been better studied than in ART naive individuals. HIV-1 is detectable in seminal plasma, at least transiently, in approximately $5-10 \%$ of men living with HIV-1 who were on ART with undetectable blood viral loads [1-5]. This presence of HIV-1 RNA in semen of ART-treated males is usually not associated with time since ART initiation, suggesting that this was not simply a slower decay of HIV-1 in semen compared to blood upon initiation of ART. It is not clear if this is related by mechanism to the HIV-1 shedding in semen of ART-naive individuals reported here.

Generally, in individuals on ART with suppressed blood viral loads $(<200 \mathrm{cp} / \mathrm{ml})$, the presence of HIV-1 RNA in semen is not associated with a detectable transmission risk, even in MSM populations with high STI rates [7]. The results presented herein are nonetheless relevant to understanding the potential tissue reservoirs of HIV-1.

What controls HIV-1 RNA shedding into semen is unclear. Although limited penetration of ART into the male genital tract may play a role, the relationship appears complex and partial [11] and does not play a role in the ART naive individuals described in this report. Notably, in ART treated males, the presence of HIV-1 RNA in seminal plasma was associated with the presence of 
cytomegalovirus (CMV) DNA, in one study [3], but not another [5]. Separately, congenital CMV infection, presumably as a proxy measure for active CMV infection in the placenta, is a strong risk factor (odds ratio $=20$ ) for mother to child transmission of HIV-1 in the face of widespread maternal ART [28]. These associations between active CMV infection and HIV-1 replication suggests that breakthrough HIV-1 replication may have a biological basis other than, or in addition to, poor penetration of ART drugs.

\section{Conclusion}

That HIV-1 populations tend to be compartmentalized between the general circulation and the male genital tract is well established $[29,30]$. Importantly, the results presented here suggest that independent HIV-1 replication in the male genital tract sometimes occurs, resulting in shedding of HIV-1 RNA into seminal plasma. Even highly effective immune responses resulting in extended periods with undetectable blood viral loads are not always sufficient to suppress this shedding. This replication could reflect that the male genital tract is the site of a persistent HIV-1 reservoir.

\section{Supplementary information}

Supplementary information accompanies this paper at https://doi.org/10. 1186/s12985-020-01300-6.

Additional file 1: Figure S1. Correlation between semen and blood viral load and presence of individuals with semen viral loads but low blood viral loads in previously published data. All graphs generated from table data in the reports except Olivier et al from supplemental figure 2B. Tachet et al analyzed 52 individuals incl 21 on ART \& did not identify who was on ART. Red circles indicate individuals with low blood viral loads and detectable HIV-1 RNA in semen. None of the reports commented on $V L$ data from these individuals. Note that $x$-axis scales do not always match and that the $y$-axis scale for Olivier et al is different from the other graphs. Graph from Olivier et al reprinted from J Infect Dis, 209, 1174-84 (2014), Olivier AJ et al, Distinct cytokine patterns in semen influence local HIV shedding and HIV target cell activation by permission of Oxford University Press.

\section{Abbreviations \\ ART: Antiretroviral therapy; CMV: Cytomegalovirus; cp: Copies; \\ DNA: Deoxyribonucleic acid; HIV-1: Human immunodeficiency virus-1; IQR: Interquartile range; LC MS/MS: Liquid chromatography tandem mass spectrometry; MLV: Murine leukaemia virus; MSM: Men who have sex with men; NSC: Nonsperm seminal cells; PBS: Phosphate buffered saline; RNA: Ribonucleic acid; STIs: Sexually transmitted infections}

\section{Acknowledgements}

We thank the donors for this project. We thank Ms. Sandra Tshisa, Ms. Louise Suka, and Dr. Johan Human for help with recruitment and study participant interviews.

\section{Authors' contributions}

JRD conceived the study and obtained funding; SMK, PS and JRD designed the study; KR recruited or oversaw recruitment of participants and interviewed or oversaw interviews of participants and completed all clinical record reviews; SMK analysed the data; JRD and CW supervised the work; JN and KC designed the drug quantification strategy and interpretation; SMK, KC and JRD wrote the first draft of the manuscript; all authors contributed to subsequent drafts, and read and approved the final manuscript.

\section{Funding}

We thank the South Africa National Research Foundation (JRD), the Poliomyelitis Research Foundation (JRD and SMK) and the International Centre for Genetic Engineering and Biotechnology (JRD and SMK) for financial support. SMK was an ICGEB Arturo Falaschi PhD trainee. The funders did not play a role in the design of the study or collection, analysis, or interpretation of data or in the writing of the manuscript.

\section{Availability of data and materials}

The data supporting the conclusions of this article are included within the article.

Ethics approval and consent to participate

Study participants gave written informed consent. This study was approved by the Human Research Ethics Committee of the University of Cape Town Faculty of Health Sciences (ref 727/2014). This study was in accord with the requirements of the Helsinki Declaration.

\section{Consent for publication}

No individually identifiable patient information or image is present in this report.

\section{Competing interests}

The authors declare that they have no competing interests.

\section{Author details}

${ }^{1}$ Division of Immunology, Department of Pathology, University of Cape Town, Anzio Rd, Observatory, Cape Town 7925, South Africa. ${ }^{2}$ International Centre for Genetic Engineering and Biotechnology, Cape Town, South Africa. ${ }^{3}$ Department of Biological Sciences, School of Science, University of Eldoret, Eldoret, Kenya. ${ }^{4}$ Division of Medical Virology, Department of Pathology, University of Cape Town, Cape Town, South Africa. ${ }^{5}$ Virology Unit, Department of Biomedical Sciences, Institute of Tropical Medicine, Antwerp, Belgium. ${ }^{6}$ Division of Clinical Pharmacology, Department of Medicine, University of Cape Town, Cape Town, South Africa. ${ }^{7}$ Anova Health Institute, Cape Town, South Africa. ${ }^{8}$ Division of Infectious Diseases and HIV Medicine, Department of Medicine, University of Cape Town, Cape Town, South Africa. ${ }^{9}$ Institute for Infectious Disease and Molecular Medicine, University of Cape Town, Cape Town, South Africa. ${ }^{10}$ National Health Laboratory Service, Johannesburg, South Africa. ${ }^{11}$ Division of Virology, Faculty of Medicine and Health Sciences, Stellenbosch University, Parow, South Africa.

Received: 12 December 2019 Accepted: 20 February 2020

Published online: 05 March 2020

\section{References}

1. Lambert-Niclot S, Tubiana R, Beaudoux C, Lefebvre G, Caby F, Bonmarchand M, Naouri M, Schubert B, Dommergues M, Calvez V, et al. Detection of HIV-1 RNA in seminal plasma samples from treated patients with undetectable HIV-1 RNA in blood plasma on a 2002-2011 survey. AIDS. 2012;26:971-5.

2. Ghosn J, Leruez-Ville M, Blanche J, Delobelle A, Beaudoux C, Mascard L, Lecuyer H, Canestri A, Landman R, Zucman D, et al. HIV-1 DNA levels in peripheral blood mononuclear cells and cannabis use are associated with intermittent HIV shedding in semen of men who have sex with men on successful antiretroviral regimens. Clin Infect Dis. 2014;58:1763-70.

3. Gianella S, Smith DM, Vargas MV, Little SJ, Richman DD, Daar ES, Dube MP, Zhang F, Ginocchio CC, Haubrich RH, et al. Shedding of HIV and human herpesviruses in the semen of effectively treated HIV-1-infected men who have sex with men. Clin Infect Dis. 2013:57:441-7.

4. Mujugira A, Coombs RW, Heffron R, Celum C, Ronald A, Mugo N, Baeten JM, Partners Pr EPST. Seminal HIV-1 RNA detection in heterosexual African men initiating antiretroviral therapy. J Infect Dis. 2016;214:212-5.

5. Gantner P, Assoumou L, Leruez-Ville M, David L, Suzan-Monti M, Costagliola D, Rouzioux C, Ghosn J, Group EAES. HIV-1-RNA in seminal plasma correlates with detection of HIV-1-DNA in semen cells, but not with CMV shedding, among MSM on successful antiretroviral regimens. J Antimicrob Chemother. 2016;71:3202-5.

6. Eisinger RW, Dieffenbach CW, Fauci AS. HIV viral load and transmissibility of HIV infection: undetectable equals untransmittable. JAMA. 2019;321:451-2.

7. Rodger AJ, Cambiano V, Bruun T, Vernazza P, Collins S, Degen O, Corbelli GM, Estrada V, Geretti AM, Beloukas A, et al. Risk of HIV transmission through condomless sex in serodifferent gay couples with the HIV-positive 
partner taking suppressive antiretroviral therapy (PARTNER): final results of a multicentre, prospective, observational study. Lancet. 2019;393:2428-38.

8. Ho YC, Shan L, Hosmane NN, Wang J, Laskey SB, Rosenbloom DI, Lai J, Blankson $\mathrm{JN}$, Siliciano JD, Siliciano RF. Replication-competent noninduced proviruses in the latent reservoir increase barrier to HIV-1 cure. Cell. 2013;155:540-51.

9. Gantner P, Ghosn J. Genital reservoir: a barrier to functional cure? Curr Opin HIV AIDS. 2018;13:395-401.

10. Mittler JE, Markowitz M, Ho DD, Perelson AS. Improved estimates for HIV-1 clearance rate and intracellular delay. AIDS. 1999;13:1415-7.

11. Taylor S, Davies S. Antiretroviral drug concentrations in the male and female genital tract: implications for the sexual transmission of HIV. Curr Opin HIV AIDS. 2010;5:33543.

12. Gupta P, Mellors J, Kingsley L, Riddler S, Singh MK, Schreiber S, Cronin M, Rinaldo CR. High viral load in semen of human immunodeficiency virus type 1-infected men at all stages of disease and its reduction by therapy with protease and nonnucleoside reverse transcriptase inhibitors. J Virol. 1997;71:6271-5.

13. Liuzzi G, Chirianni A, Clementi M, Bagnarelli P, Valenza A, Cataldo PT, Piazza M. Analysis of HIV-1 load in blood, semen and saliva: evidence for different viral compartments in a cross-sectional and longitudinal study. AIDS. 1996;10:F51-6.

14. Tachet A, Dulioust E, Salmon D, De Almeida M, Rivalland S, Finkielsztejn L, Heard I, Jouannet P, Sicard D, Rouzioux C. Detection and quantification of HIV-1 in semen: identification of a subpopulation of men at high potential risk of viral sexual transmission. AIDS. 1999:13:823-31.

15. Eron JJ Jr, Smeaton LM, Fiscus SA, Gulick RM, Currier JS, Lennox JL, D'Aquila RT, Rogers MD, Tung R, Murphy RL. The effects of protease inhibitor therapy on human immunodeficiency virus type 1 levels in semen (AIDS clinical trials group protocol 850). J Infect Dis. 2000;181:1622-8.

16. Olivier A, Masson L, Ronacher $\mathrm{K}$, Walz G, Coetzee D, Lewis DA, Williamson AL, Passmore JA, Burgers WA. Distinct cytokine patterns in semen influence local HIV shedding and HIV target cell activation. J Infect Dis. 2014;209:1174-84.

17. Kalichman SC, Di Berto G, Eaton L. Human immunodeficiency virus viral load in blood plasma and semen: review and implications of empirical findings. Sex Transm Dis. 2008;35:55-60.

18. Shepard RN, Schock J, Robertson K, Shugars DC, Dyer J, Vernazza P, Hall C, Cohen MS, Fiscus SA. Quantitation of human immunodeficiency virus type 1 RNA in different biological compartments. J Clin Microbiol. 2000;38:1414-8.

19. Dulioust E, Tachet A, De Almeida M, Finkielsztejn L, Rivalland S, Salmon D, Sicard D, Rouzioux C, Jouannet P. Detection of HIV-1 in seminal plasma and seminal cells of HIV-1 seropositive men. J Reprod Immunol. 1998:41:27-40.

20. Winter AJ, Taylor S, Workman J, White D, Ross JD, Swan AV, Pillay D. Asymptomatic urethritis and detection of HIV-1 RNA in seminal plasma. Sex Transm Infect. 1999;75:261-3.

21. Klein K, Nickel G, Nankya I, Kyeyune F, Demers K, Ndashimye E, Kwok C, Chen PL, Rwambuya $\mathrm{S}$, Poon $\mathrm{A}$, et al. Higher sequence diversity in the vaginal tract than in blood at early HIV-1 infection. PLoS Pathog. 2018;14:e1006754.

22. Semugoma NP, Rebe K, Sonderup MW, Kamkeumah M, De Swardt G, Struthers H, Eksen H, Mclintyre J. Hepatitis C. A South African literature review and results from a burden of disease study among a cohort of drug-using men who have sex with men in Cape Town, South Africa. S Afr Med J. 2017:107:1116-20.

23. Chaix ML, Boufassa F, Meyzer C, Leruez-Ville M, Mahjoub N, Nere ML, Genet P, Duvivier C, Lascoux-Combes C, Lambotte O, Ghosn J. Detectable HIV-RNA in semen of HIV controllers. PLoS One. 2017;12:e183376.

24. Ganor Y, Real F, Sennepin A, Dutertre CA, Prevedel L, Xu L, Tudor D, Charmeteau B, Couedel-Courteille A, Marion S, et al. HIV-1 reservoirs in urethral macrophages of patients under suppressive antiretroviral therapy. Nat Microbiol. 2019:4:633-44.

25. Jacob RA, Moyo T, Schomaker M, Abrahams F, Pujol BG, Dorfman JR. Anti-V3/glycan and anti-MPER neutralizing antibodies, but not anti-V2/glycan-site antibodies are strongly associated with higher anti-HIV-1 neutralization breadth and potency. J Virol. 2015;89:5264-75.

26. la Porte CLLBD, Back DJ, Blaschke T, Boucher CAB, Fletcher CV, Flexner C, Gerber JG, Kashuba ADM, Schaprio J, Burger DM. Updated guidelines to perform therapeutic drug monitoring for antiretroviral agents. Rev Antivir Ther. 2006;3:4-12.

27. Jackson A, Moyle G, Watson V, Tjia J, Ammara A, Back D, Mohabeer M, Gazzard B, Boffito M. Tenofovir, emtricitabine intracellular and plasma, and efavirenz plasma concentration decay following drug intake cessation: implications for HIV treatment and prevention. J Acquir Immune Defic Syndr. 2013;62:275-81.

28. Pathirana J, Groome M, Dorfman J, Kwatra G, Boppana S, Cutland C, Jones S, Madhi SA. Prevalence of congenital cytomegalovirus infection and associated risk of in utero Human Immunodeficiency Virus (HIV) acquisition in a high-HIV prevalence setting, South Africa. Clin Infect Dis. 2019;69:1789-96.
29. Kariuki SM, Selhorst P, Ariën KK, Dorfman JR. The HIV-1 transmission bottleneck. Retrovirology. 2017;14:22-40.

30. Joseph SB, Swanstrom R, Kashuba AD, Cohen MS. Bottlenecks in HIV-1 transmission: insights from the study of founder viruses. Nat Rev Microbiol. 2015;13:414-25.

\section{Publisher's Note}

Springer Nature remains neutral with regard to jurisdictional claims in published maps and institutional affiliations.
Ready to submit your research? Choose BMC and benefit from:

- fast, convenient online submission

- thorough peer review by experienced researchers in your field

- rapid publication on acceptance

- support for research data, including large and complex data types

- gold Open Access which fosters wider collaboration and increased citations

- maximum visibility for your research: over $100 \mathrm{M}$ website views per year

At BMC, research is always in progress.

Learn more biomedcentral.com/submissions 